\title{
SHIPYARD WORKERS, NEW ORLEANS, AND U.S. DEMOCRACY
}

Aaron Schneider

\begin{abstract}
This project explores the civic engagement of workers in the Avondale shipyard on the outskirts of New Orleans. Avondale workers earn decent incomes, patronize local businesses, join associations and support those organizations with their leadership, contributions, and civic engagement. This engagement creates the social capital that holds the community together, training people to take an interest in the public good, and driving them to seek political information. As leaders in the community, Avondale workers share that information with family, friends, and fellow workers, and build the sense that they can participate effectively in public life. They are politically engaged, vote at high rates, and participate in democratic life. The workers themselves are clear on where their civic activism comes from - the struggle and victory of securing union representation in the workplace. That struggle was difficult, and it taught workers to intertwine their civic future with that of the community. It also secured the material benefits of income and stability that allowed workers to plan for a lifetime of increasing productivity, income, and generational advancement.
\end{abstract}

Keywords: Civic Engagement; Social Capital; Unions; Labor; New Orleans; Political Economy.

\section{Resumo}

Esse estudo explora a engajamento cívico dos trabalhadores do estaleiro Avondale na fronteira de New Orleans. Os trabalhadores de Avondale ganham uma renda decente, compram em empresas locais, associam-se a grupos cívicos e apóiam essas organizações com liderança, contribuições e engajamento cívico. Este engajamento constrói o capital social que mantém a comunidade, ensinando pessoas a pensar no bem público, e impulsionando-os a procurar informação política. Como líderes da comunidade, os trabalhadores de Avondale compartilham esta informação com familiares, amigos e outros trabalhadores, e constróem o sentimento de que podem participar efetivamente na vida pública. São engajados politicamente, votam apresentando altas taxas deste tipo de participação e participam na vida democrática. Os trabalhadores têm claro de onde vem seu ativismo - a luta e vitória de representação sindical no estaleiro. Esta luta foi difícil e ensinou aos trabalhadores entrelaçar seu futuro cívico com o futuro da comunidade. Também assegurou benefícios materiais de renda e estabilidade no emprego que possibilitou aos trabalhadores planejar para uma vida de crescente produtividade, renda e avanço geracional.

Palavras-chave: Engajamento Cívico; Capital Social; Sindicatos; Trabalho; New Orleans; Economia Política. 


\section{Introduction}

The greater New Orleans region is home to approximately 530,000 jobs. Of that total, only a few are good. The work available to the vast majority of people is at the entry-level in tourism, hospitality, and food services. Most jobs available pay poor wages, with limited stability, low possibility for advancement, and few opportunities for workers to improve workplace conditions. The only sector that provides a reasonable number of good jobs for people with the educational and demographic characteristics of the majority of New Orleanians is manufacturing, and only some manufacturing jobs can be considered good.

The primary source of decent manufacturing work in the New Orleans area is the Avondale shipyard, and it is also the largest single employer in the state of Louisiana. At its peak, the yard provided over 17,000 jobs, and almost 4000 people currently work there (TIMES PICAYUNE, 2011). After a lengthy struggle, the workers in the yard secured union protections, and they have built a shipyard with good wages, decent benefits, safe working conditions, and career stability. Their work has produced barges, commercial supertankers, cruise ships, steam boats, destroyers, and even a floating jail for New York when the state government sought to relieve prison overcrowding.

Significantly, Avondale offers a trajectory of growing productivity and income security for large numbers of men and women with less than a college education, making it possible for them to enter at a young age, apprentice, work their way up the hierarchy, and count on a steady trajectory of reasonable comfort earned through a lifetime of hard, and proud, work. These workers send their kids to college, contribute to their churches, join neighborhood associations and other civic groups, follow current events, engage politically with their friends, family and community, and generally offer the active citizenry that anchors communities. These pillars of the community came back after Katrina and made it possible for their neighbors and the rest of the New Orleans area to come back. Avondale jobs and the kinds of workers they produce are essential ingredients to the active and civic democracy on which this nation was built.

Yet, Avondale shipyard is scheduled to close in 2013. The federal government and the state government have made a reported $\$ 500$ million available to save the jobs at Avondale, but there is as yet no deal to save the shipyard (THOMPSON, 2011). The current article emphasizes the importance of the stable, decent livelihoods at Avondale that allow people to join organizations, feel confident about political participation, actively engage their community, and meaningfully participate in their government. 


\section{A SITUAÇÃO DAS AMÉRICAS: \\ DEMOCRACIA, CAPITAL SOCIAL E EMPODERAMENTO}

\section{Citizenship and Democracy}

An engaged citizenry is the bedrock of democracy in America. American culture, at least in its early decades, was defined by the eagerness of citizens to organize and associate. These associations led people into public life, and it was there that they learned to look beyond narrow interest and consider the public good. This willingness to associate, sacrifice, and act in concert protected American freedom and democracy despite the newness of the nation, inequalities of wealth and station, and the rifts of ethnicity and race, even in the years leading to the civil war.

When Alexis de Tocqueville observed American democracy in 1831, he marveled at the ability to join in civic association. "Nothing, in my opinion, is more deserving of our attention than the intellectual and moral associations of America" he wrote (DE TOCQUEVILLE, 2003, p. 149). Groups of citizens came together for collective goals, defining their wants and training the skills that would articulate their interests in the public sphere. The unique institutions of early modern America made possible this articulation, as decentralized power, frequent elections, and town hall meetings in particular provided ample opportunity for citizens and groups to practice their civic skills, "town meetings are to liberty what primary schools are to science; they bring it within the people's reach, they teach men how to use and enjoy it" (DE TOCQUEVILLE, 2003, p. 37) ${ }^{1}$.

Many have argued that contemporary America has lost its civic culture as a result of modernization, urbanization, and political changes. People no longer join, engage, and participate communally the way they; they are all "Bowling Alone," atomized in the world and without the myriad associations that enable collective and civic action to protect democracy, "Americans are right that the bonds of our communities have withered, and we are right to fear that this transformation has very real costs" (PUTNAM, 2001, p. 402). Putnam locates this decline in the recent past, a phenomenon of the last few decades or so, "over the course of the last generation or two, a variety of technological, economic and social changes have rendered obsolete the stuff of American social capital" (PUTNAM, 2001, p. 2).

\footnotetext{
${ }^{1}$ Engagement in public life is the essence of American democracy, and de Tocqueville marveled at our capacity for political activity. "The political activity which pervades the United States must be seen in order to be understood. No sooner do you set foot upon the American soil, than you are stunned by a kind of tumult; a confused clamor is heard on every side [...] Everything is in motion around you; here, the people of one quarter of a town are met to decide upon the building of a church; there, the election of a representative is going on [...] The cares of political life engross a most prominent place in the occupation of a citizen in the United States [...] This ceaseless agitation which democratic government has introduced into the political world influences all social intercourse. I am not sure that upon the whole this is not the greatest advantage of democracy; and I am much less inclined to applaud it for what it does, than for what it causes to be done" (DE TOCQUEVILLE, 2003, p. 200).
} 
There are multiple explanations for the decline of civic engagement. One explanation emphasizes technological change, as people no longer need associations to secure information, make interests known, or even provide social support (RIDLEN RAY, 1999). As radio, television, and internet replaced word of mouth as sources of information, people no longer depended on direct contact to develop civic knowledge. Technological change made information easier to obtain, but it also removed the social and political content from the act of seeking information. As a result, the modern age is paradoxically characterized by more information but less association.

Another compelling explanation for the decline of civic engagement is the role of powerful, single-issue or narrow partisan interest groups. They expanded their influence as politics came to be an increasingly national affair waged by slick, national organizations instead of local citizens in community debates. This impoverished democracy by removing the role of the citizen and community activist who mobilizes and connects through local issues to national struggles (BERRY, 1999). Mass media dumbs down the issues; campaigns are financed by millionaire fundraisers; advocacy organizations and lobbyists dominate the decision-process; political parties eliminate the uncertainty of elections by turning every district into a safe district (BULLOCK, 2010). Together, these factors remove power from citizens and locate decisions in faraway politicians swayed by powerful lobbyists and disconnected advocates.

This problem is particularly acute for poor and working people. In the words of Schlozman, Verba and Brady (1999, p. 431), working people do not participate because "they can't, they don't want to, and nobody asked". By definition, poor and working people lack the money that might buy them influence, and they lack the time as they are too busy trying to survive. This means that they never develop the civic skills necessary to engage, and they fail to develop an interest in politics. Ultimately, they are isolated from the social and political networks that might overcome these obstacles to mobilize people into public life (SCHLOZMAN, VERBA and BRADY, 1995).

This discussion holds relevance for Avondale, the workers it supports, and the civic life of New Orleans. While the rest of the country and working people in general have lost their collective voice and their civic engagement, Avondale workers remain the pillars of their community. They hold New Orleans together.

Avondale provides good jobs, and good jobs provide income that makes it possible for people to patronize local businesses, contribute to charity, participate in houses of worship, and otherwise be the heart and soul of local associational life. Out of the working people of New Orleans came jazz, Mardi Gras second lines, and the distinctive New Orleans sandwich - the 
Po' Boy ${ }^{2}$. Each evolved as a characteristic expression of working people's associational life. With a good income and stable career, workers at Avondale feel confident to engage their friends and neighbors; secure the information they need to develop organizational and civic skills; and participate in communal associations.

Avondale jobs are especially good because they create the networks of information, support, security, and skills that allow a person to operate in the workplace, and in life, as a reliable colleague. Avondale jobs provide these kinds of life lessons at least in part because Avondale jobs are unionized. Unionization has secured income, promotions, and stability that all workers at Avondale enjoy, whether or not they are members. More importantly for the current discussion, unions teach workers how to operate as members of an organization and a community. Membership gives workplace communication, organizational, and leadership skills to participate in meetings, organize activities, and assume leadership roles as shop stewards, counselors, and members, and these skills are directly transferable to communication, organization, and leadership in communities. Church reverends, neighborhood association members, and civil rights activists draw on their unionization experience at Avondale to inform and facilitate their activism in their communities.

This section has argued that American democracy depends on the active citizens produced by jobs like those at Avondale. Before turning to the empirical evidence drawn from surveys of Avondale workers, the next section describes in more detail some of the concepts related to active and engaged communities.

\section{Building Blocks of Civic Engagement}

At heart, all discussions of active engagement develop the theoretical propositions that engagement is necessary to realize a full life; collective and public action is superior to individual and atomized behavior; and an active and informed populace is necessary to a healthy democratic polity (GALSTON, 2001). The concepts that make up this framework are linked. People in possession of human capital assets can potentially take action, but only if they also possess the social capital that allows them to join in pursuit of collective actions. Collectively, they can contribute to and function within a community, engaging issues of common concern. In the process, they gather and exchange information and build a sense of political efficacy, the sense

\footnotetext{
2 The original "poor boy" sandwich was given away to attract workers to purchase nickel beers at lunch time. The sandwiches began as a loaf of French bread cut in half and stuffed with cheap, readily available local seafood, and have evolved into the delicacies of today. Jazz emerged from the musical entertainment of port and manufacturing workers, whose steady wages spent in local dives cultivated experimental local talent until it could graduate to the high-class dance halls and speak-easies of prohibition.
} 
that their collective actions around common goals can be pursued within the political sphere. Here they enter politics, participating politically in the myriad forms that support a vibrant and active democracy.

Without a basic minimum of human capital, people cannot be expected to enter the public sphere. Human capital entails things like income, education, health, and organizational skills; it is the set of things that people can possess, in material or other forms. Amartya Sen translates the concept of human capital into the notion of capabilities, the ability to do things, the result of combining endowments and assets to pursue goals (SEN, 2005) ${ }^{3}$. As will be evident in the discussion of Avondale workers, human capital is both a prerequisite for civic engagement and it is also the product of successfully engaging. Workers won material and organizational benefits, and this in turn allowed them to contribute to their community ${ }^{4}$.

Associational activity takes more than simply the human capital of workplace activity; it also requires overcoming the many obstacles to joining with others. The glue that holds individuals together has been referred to as social capital, a concept traced in particular to sociologist James Coleman (1988). For Coleman, social capital was constituted by the social ties and shared norms that fill in the gaps in individual behavior, for example the bonds of trust that allow market operations to function. Without social capital, individuals are unable to exchange, especially if an exchange is to occur over an extended period, as in a loan or a long-term contract. Shared ideas, communication, and networks simplify interaction and allow people to enter relationships that would otherwise be impossible.

Putnam brings the same logic to the study of political life in his comparison of Northern and Southern Italian democracy. He argues that "making democracy work" in Northern Italy depends on a set of shared associations and overlapping bonds that allows individuals to collaborate in governance (PUTNAM, 1994). While the associations that Putnam identifies, choirs and other cultural organizations, are not necessarily political, they provide the bonds of trust and networks of communication that allow individuals to pursue collective ends. Through these networks, political information is gathered, accumulated, and disseminated, and it is on the basis of shared information that political action becomes possible (GALSTON, 2001).

Political action requires further psychological preparation, a feeling of efficacy that efforts will make a difference. Political scientists tend to divide efficacy into internal and external dimensions. Internal efficacy is the degree to which people think that their efforts matter. Without a sense of internal

\footnotetext{
3 Sen roots his capabilities approach in the concepts of "necessities", "human freedom", and "human flourishing", all of which go much beyond the immediate material notion of capital and into a broader range of human potentials (SEN, 1993).

${ }^{4}$ There is an inter-relationship between material well-being and civic engagement (USLANER and BROWN, 2005).
} 
efficacy, it is all too easy to abstain from political action - why bother voting if a single vote does not matter ${ }^{5}$ ? External efficacy is the degree to which people believe their government and public officials pay attention to them (VALENTINO, GREGOROWICZ and GROENENDYK, 2009).

Empowered with the sense that their actions matter for what government does, people with feelings of efficacy participate in politics (KENNY, 1992). This can take the form of voting, signing a petition, joining a rally, and many other political acts which are civic, collective, bonded by social capital, and mobilizing human capital contributions of material support, organizational skills, and leadership. Democracies with limited amounts of political participation may survive, but they are surely less representative than participatory democracies, and possibly less democratic. As the data below will show, Avondale workers make important contributions to the civic life of New Orleans and its environs. They possess human capital, collaborate with other members of the community, gather political information, feel efficacious, and act politically.

\section{Observations $^{6}$}

The sections that follow describe information gathered from Avondale workers in the form of surveys and focus groups. Focus groups were held with approximately ten workers invited by union leaders to discuss their experience at Avondale, their pride in their work, and their role in their communities. In particular, union members were invited on the basis of their knowledge of the history of the shipyard, their role in the union and the struggle to secure a union, and their role as religious or other kinds of leaders in the community. Based on these focus groups, a survey instrument was designed to capture the working life and community engagement of Avondale workers.

The survey included 82 questions applied to 84 respondents using a variety of survey methodologies, including take-home surveys and in-person surveys applied by an interviewer ${ }^{7}$. There was no significant difference across

\footnotetext{
${ }^{5}$ For some, it is through the process of democratic deliberation that people gain a sense of internal political efficacy, not the other way around (MORRELL, 2005).

6 The survey instrument was designed with the help of Ron Mancoske from the Southern University of New Orleans and Nick Unger from the AFL-CIO. Surveys were applied by various student and volunteer assistants, including: Mike Barr, Andrew Brooks, Tasneem Chowdhry, Sarah Mandel, David McCoy, Anna Schumacher, Kyle Shepherd, Stephanie Sullivan, and Zach Ulrich.

${ }^{7}$ We used multiple methods because our first effort, asking shop stewards to hand out surveys to workers, produced 38 responses, a low rate that offered an initial indication of the low morale and high levels of stress facing workers. To secure more responses, student workers and the principal investigator went to the gate of the shipyard. At first, surveyors attempted to secure responses in the lunch break in the middle of their shift, but with only 30 minutes, many workers politely apologized and declined. With time to publication rapidly approaching, a final strategy to secure responses placed surveyors at the gate of the shipyard when workers left their shifts. It was truly
} 
the survey methods in terms of the detail in the responses. The only difference was that we removed some of the more open-ended and more thought-provoking questions from the original survey instrument for application in person. While these questions seemed appropriate to a takehome survey where workers would have time to ponder their response, they were not appropriate to a survey applied in-person and under the pressure of workers generously giving their time as they headed to their cars on their way home to family. The sections below describe the data from the surveys in terms of the good jobs at the shipyard, the good neighbors, members of the community, and citizenry produced by Avondale, and the risk facing New Orleans and our democracy if we the yard closes. Where appropriate, evidence from the focus groups will also be included ${ }^{8}$.

\section{Data}

The surveys demonstrated some fairly clear patterns among the workers and their role in the community. The tables in the appendix present the full results compared to national averages, where available. Major highlights and significant contrasts with national patterns are discussed in the text below.

The average age of respondents was 48 , with a few younger than 30 , and the bulk of the workers were between 30 and 70 . Of the total, 47 percent of the workers were between 30 and 50 , and 38 percent of the workers were over 50 . The oldest worker surveyed was 66 . A majority of the workers, $62 \%$, were married, and workers shared their home with an average of slightly fewer than three family members, with the largest household comprised by 12 family members. Exactly half of the workers were African American, with 28 percent white, 11 percent Latino, and 11 percent other. There was a small cohort of women workers, at 11 percent of the sample.

Of the workers asked about their education, 8 percent of the workers had completed college, with 24 percent completing some college, 8 percent completing an associate's degree, 44 percent with a high school or GED, and

\footnotetext{
an experience. When the whistle blows, the one thousand workers ending their shift materialize over the levee, visible at first only as hard-hats bobbing over the lip of the berm. As heads and bodies slowly materialized, an eventual sea of workers cascaded down the levee, hopping over guard rails and retaining walls to make their way to the gates where they punched out. Now within sight of the parking lot, they lumbered past, eager to get to their car and beat traffic home. Many smiled and waved as they went past, apologizing for some domestic obligation that prevented them from delaying, but a sufficient number paused to ask our business and/or agreed to respond to the survey.

${ }^{8}$ Identities of workers were separated from their responses, and in the results below workers are identified only as "focus group participant" or "survey respondent".
} 
16 percent with less than a high school education ${ }^{9}$. These results reflect New Orleans metro averages, where 27 percent of the people completed college, 16 percent completed less than high school (ORTIZ, 2011), and functional illiteracy is between 24 and 32 percent $^{10}$.

Despite the difficulties of having been born to an area with poor educational results, the workers of Avondale demonstrated long and successful working lives. On average, they had worked at Avondale for thirteen years, with a third of the workers working fewer than five years and a quarter working over 20 years. The data showed a somewhat curious pattern among the workers in terms of length of time worked, with a large number of workers between zero and ten years, a slight dip in workers between 11 and 20 years, and another large concentration of workers with more than 20 years of experience ${ }^{11}$.

Another observation was more telling about the typical working life in the shipyards. A 55 year-old welder described his work trajectory as one in which he joined the shipyard at 22 after serving four years in the military. At the yard, he apprenticed his skills up and worked as a welder for five years, only to leave to enter the welding trade at another firm when work slowed at the yard. After being called up to military service, he rejoined Avondale once again. Since then, he has worked at Avondale for six to ten year stretches when there is a demand for workers, and in between he has been able to turn the skills he trains up at Avondale into work in other large-scale manufacturing firms (FOCUS GROUP, 06/11/2011).

This career pattern provides a stream of relatively steady income for the workers. Almost all the workers asked owned a car, 89 percent, and over half owned their homes, at 60 percent, well over the New Orleans area average rate of ownership of 47 percent (ORTIZ, 2011). Most workers appear to stay in the same home for long periods, with an average of 15 years at the same address and a maximum of 59 years at the same place. In the focus groups, workers described the access to credit that Avondale provided, supporting a credit union and a general infusion of liquidity that kept things moving in the housing and other long-term purchases. One worker remarked, "It used to be that all you had to do was go to the bank and tell them that you work at Avondale and they would write you a loan right then and there."

\footnotetext{
${ }^{9}$ This was consistent with observations of the Louisiana Workforce Commission, which indicated that many workers were not computer literate or not literate at all, and thus unable to access state services (INTERVIEW LCW, 11/16/2011).

10 National Center for Education Statistics website. Available: <http://nces.ed.gov/naal/estimates/StateEstimates.aspx>. Checked on: 19 nov. 2011.

${ }^{11}$ Several explanations for these patterns came from the focus group discussions. The first was that Katrina disrupted work patterns for all workers, and at exactly 6 years ago in 2005, it may have depleted some of the workers who would have by now accumulated between 11 and 20 years. A second observation is that there was a lull in defense spending in the years prior to September 11, 2001, and the slowdown in military spending might have corresponded to lower levels of activity and hiring in the shipyard.
} 
The youngest member of the focus group, a recent hire who was 21 years old, explained that with the threat of closing, he was not give the same options. "They closed the credit union, and when I went to a bank for a car loan, they told me they couldn't be sure I'd be able to pay in the future" (FOCUS GROUP, 06/06/2011).

Workers also patronize local businesses, with some workers shopping for food seven days a week, and all workers averaging at least 2.3 food shopping trips per week. Workers also support local restaurants, eating out 2.1 times per week, on average, and a maximum of ten times per week. They visit the drug store an average of 3.1 times per week and a maximum of 15 times. When asked what they would do if the shipyard closed, workers in the focus group described cutting back on eating out, extra-curricular activities for their kids, new appliances, and home improvements (FOCUS GROUP, 06/08/2011).

The potential shutdown of the yard was a looming cloud for the workers. Every month a new round of layoffs has been occurring, starting in October of 2010. Despite promises to keep workers as long as possible and hunt for a new set of contracts or a buyer for the yard, steps to close the yard have been occurring in parallel, something that is not lost on the workers. The workers deal with the stress in a variety of ways, though surprisingly few drink alcohol. Almost half the workers, 46 percent, reported taking not a single drink in the last month; and, on average workers reported having a drink 4.7 days of the last 30 , with 80 percent reporting a maximum of three drinks on any occasion. When asked about these responses, the workers described the discipline and pace of work. "I climb seven stories of stairs four times a day to do my work, and I have to concentrate every second once I'm up there. The last thing I need is to be slow" (SURVEY RESPONDENT, 11/04/2011).

Still, the stress is palpable. For an average of one week during the last month, 7.4 days, workers reported being "worried, tense or anxious." Seventy-three percent of workers reported those feelings at least once; 23 percent felt that way two-thirds of the time, 20 days out of 30 ; and ten percent felt worried, tense or anxious all month. Over the same period, workers reported "not enough sleep" an average of 9.4 days, with 81 percent missing sleep at least once, 76 percent not getting enough sleep at least half the month, and 10 percent missing sleep every single night. One worker, in the midst of filling out the survey, suddenly tore the paper and stuffed it in his pocket, "I can't handle all these questions about stress. I'm 58 years old, and I've got nothing to do when I get home. If the yard closes, I don't know what happens to a guy like me" (SURVEY RESPONDENT, 10/28/2011).

Workers talk frequently about the threatened closing with their colleagues, friends and family. For 42 percent of the workers, the issue is a topic of discussion every single day, and 95 percent of the workers discuss the closing at least once a week. The workers are proud of the work they have 
done at Avondale; in fact only one worker surveyed reported being "not proud at all". The other 99 percent of workers were at least slightly proud, and the great majority, 82 percent, was either "very" or "extremely" proud. This translates into anger at the potential closing, with 76 percent reporting being either "very angry" or "extremely angry" when they think about the closing of the yard, and only 11 percent feeling not angry at all.

Still, even in the face of the pressure and stress of a potential closing, these workers care for their community. In the last month, they spent an average of eight days caring for a family-member or friend who has a "health problem, long term illness, or disability". For 14 percent of the workers, they offer such care every day, and over half of the workers, 51 percent, offer care at least one day a month. For one participant in the focus groups, the ability to care was a product not only of work, but the way work was managed, with the participation of workers in a unionized shop.

\begin{abstract}
Seeing the transition from a non-union to a union shop was huge. As a minister, I even see it as an improvement of religious ethics. As a result of my work at Avondale, I learned to minister to my people in the community differently. I could take my lessons from the union to help minister to people outside (FOCUS GROUP, 06/08/2011).
\end{abstract}

The role of Avondale workers as pillars of the community was even more evident after Katrina, when most workers and their neighbors had to evacuate. Over two thirds of workers, 67 percent, rebuilt their own home, and 43 percent helped a family member. Exactly half, 50 percent helped another member of the community, and 52 percent helped a co-worker.

The paragraphs that follow highlight the civic impact of Avondale workers, pillars of their communities and the bedrock of democratic action in the region. The most basic forms of civic action involve membership and contributions to local associations. Over half, 54 percent of workers, are members of a church, donating an average of $\$ 150$ per month to their place of worship. The most contributed by any individual was $\$ 1000$, and 31 percent of respondents contributed over $\$ 200$ per month. The churches of the region recognize their close relationship with Avondale, as over 200 churches signed a pledge to pray for Avondale, lifting the spirits of the workers with a day of prayer dedicated to saving the shipyard. One worker observed, "I used to minister to my people in the community. Now, with the threat of closing, I see that it is inside Avondale that people are hurting. I minister to them here now" (FOCUS GROUP, 06/08/2011).

Avondale workers also participate in other forms of civic association, with 21 percent involved in a political party, 19 percent involved in their neighborhood association, 14 percent involved in sports clubs, 12 percent involved in veteran's affairs groups, 10 percent involved in organizations 
supporting civil rights, environmental protection, or professional associations, 8 percent involved in groups supporting cultural, arts, and humanities issues, 7 percent involved in groups supporting women's rights, and 6 percent active in ethnic or national origin organizations. In these organizations, workers attend meetings (52 percent), donate money (49 percent), go to public events (42 percent), get others to attend meetings and distribute information (32 percent), recruit others (29 percent), and serve in leadership positions (25 percent).

In terms of union membership, our results have to be considered somewhat skewed, as the first 38 surveys were distributed only among union members. When we removed the first 38 respondents from the sample, the percent unionized was 70 percent. This contrasts with what the union understands it membership to be, at slightly over 50 percent, and it could be the result of the fact that everyone knew the research was being conducted in collaboration with the union. Still, even if the unionization rate is slightly off, it is still far higher than the US national average of 12 percent and the Louisiana average of 4.3 percent (BLS, 2011a) $)^{12}$.

The thick networks of communication built up through union activism produce high levels of political interest and information. Workers read the newspaper, watched local television news, listened to radio newscasts, or went online to get news, with 73 percent of workers seeking news every day, 16 percent at least once a week, and only 4 workers reporting never seeking any news at all. This is much higher than the national average of a maximum of 50 percent who watch television news, with radio, newspaper and internet scoring lower (ANES, 2010-2012).

Over two out of three workers, 68 percent, "strongly agreed" or "agreed" with the statement that they were "very interested in politics," and over 65 percent agreed or strongly agreed that they were "as well informed about politics as most people," compared to a national average of only 23 percent (ANES, 2000). When responding to the statement that they have a "pretty good understanding of the important political issues facing our area", workers agreed or strongly agreed 73 percent of the time about the same as the national average of 76 percent (ANES, 2008), and 45 percent disagreed or strongly disagreed with the statement that politics and government seem so complicated that "a person like me can't really understand what's going on", somewhat higher than the national average of 31 percent (ANES, 2008).

As politically interested and informed individuals, workers demonstrated high rates of interaction with others when it came to sharing and cultivating political and social knowledge. Workers discussed politics frequently, with 86 percent "discussing politics" at least once a week and 23 percent discussing politics between five and seven days a week. They also

\footnotetext{
${ }^{12}$ Bureau of Labor Statistics website. Available: <http://www.bls.gov/news.release/union2.nr0.ht m>. Checked on: 19 nov. 2011.
} 
discussed labor issues at high rates, at 71 percent, and 62 percent of workers reported discussing civil rights or women's rights in the last year.

Avondale jobs also produce workers who feel like their efforts made an impact. This is true for their personal development, as well as their political efficacy. In one focus group, a younger worker explained

I really look up to these old guys. Like them, I want to progress myself, to learn new skills, to make myself better like they've improved themselves. I learned to understand work and life in a different way; if someone says I can't do something, now I just want to do it more, do it better. I took this job thinking that I was taking a career, a place I could work for 20, 40 years and more (FOCUS GROUP, 06/08/2011).

The confidence that comes with this kind of empowerment translates also to political efficacy, with workers showing rates in some cases higher than national averages. When presented with the statement that "I don't think public officials care much what people like me think", 55 percent agreed or strongly agreed, and workers strongly disagreed or disagreed 46 percent of the time when presented with the statement that "there is not much someone like me can do to affect what the government does". When asked if they agree that they "don't have any say about what the government does", 48 percent strongly disagreed, somewhat higher than the national average of 41 percent (ANES, 2004).

In terms of external political efficacy, Avondale workers also showed results somewhat higher than the national average. When presented with the statement that "I consider myself well qualified to participate in politics", workers agreed or strongly agreed 46 percent of the time, as compared to the national average of 33.6 percent (ANES, 2000 and 2004)Workers also agreed or strongly agreed with the statement that they "could do as good a job in public office as most other people" at a rate of 32 percent, similar to the national average of 36 percent (ANES, 2000 and 2004).

These rates of political information and efficacy produced real action, with Avondale workers turning their knowledge and sense of efficacy into public engagement. In the past year, which included the midterm elections of 2010, Avondale workers reported voting at a rate of 71 percent, far higher than the national reported voting rate of 41 percent, and higher even than the national turnout for the presidential election of 2008, 62 percent, which was the highest percentage of the population voting since $1968^{13}$.

Avondale workers reported relatively high rates of other forms of political engagement, also. In the past year, 49 percent had signed a petition,

\footnotetext{
${ }^{13}$ Data compiled from Federal Elections Statistics. Available: <http://elections.gmu.edu/Turnout .html>. Checked on: 19 nov. 2011.
} 
39 percent had attended a city government or other official meeting, 37 percent had attended a meeting to discuss labor issues, 29 percent had attended a neighborhood meeting, 24 percent had contacted an elected official, 20 percent had attended a march, rally, demonstration, or protest, and 15 percent had attended a meeting to discuss politics. This compares favorably to national averages, in which 8 percent had attended a meeting to discuss politics and 16 percent had contacted an elected official ${ }^{14}$.

In sum, Avondale jobs produce workers who are active members of their community. They patronize local business, care for others, join associations, gather and disseminate information, including political information, feel efficacious in terms of their ability to influence politics, and act within the public sphere. In most of these areas, Avondale workers perform at or above national averages, suggesting that the income, stability and skills that Avondale provides prepare them to be engaged members of the community.

\section{Explaining Avondale}

The preceding section reviewed some of the data from the survey and the focus groups of Avondale workers. The discussion begs the question, why did Avondale create good jobs? Some insights into this question can be drawn from the surveys and especially the focus groups. To the extent possible, the paragraphs that follow draw directly on the workers, who tell the story of good jobs and political engagement in their own words. Good jobs are won, and it is the process of struggle to redefine the nature of work that gives workers the material means to be active members of the community, the organizational skills to pursue collective goals, and the sense of rights to exercise civic action and political efficacy. This contrasts with sectors in which workers have been unable to struggle and achieve the same defense of dignity.

The most illuminating comments were frequently those allowed by open-ended questions, such as the end of the surveys, when workers were given an opportunity to reflect on what they might do if the shipyard shuts down. Some were pragmatic, if somewhat hopeful, "I hope I can land the same kind of work, and if not, I'll find something else". Others were more pessimistic, "I will have to move away, maybe to Mississippi, where they might keep the other yard open". Still others were downright dark, "I'm buying a gun. If the shipyard dies, the community dies, and when communities die, there is crime. It's gonna be bad" (survey respondents, various days). One of the workers in the focus groups had similarly worried,

\footnotetext{
${ }^{14}$ American National Election Statistics survey of 2008. Available: <http://www.electionstudies.or g/studypages/download/datacenter_all.htm >. Checked on: 29 nov. 2011.
} 
If wages are right, then a young man sees this as an opportunity. He'll get off the streets and go get his GED, get himself a job here. Avondale even trained people up, paid you to go to school full time, get that engineering degree, and then you come back and work even higher. Without Avondale, what will be left? I'll tell you what, it's the street. You never get that kid off the street, and there you go, that's where you get problems. If there are no places with wages that are right, what choice do they have (FOCUS GROUP, 06/08/2011).

Only six years ago, the New Orleans area was shaken by Hurricane Katrina, and the disaster coincided with a longer-term decline in which the city steadily lost population and economic activity, especially in manufacturing. Manufacturing jobs are especially important because people whose productivity would otherwise be low could be turned into active members of the community. Manufacturing workers gained income, stability, and skills and this translated into economic wealth as well as social and political capital in the sense of active and engaged communities. As one worker in the focus group reflected with apparent pride,

That's what you get with good jobs. You get teachers, military vets, people with degrees, women. All of them know that this is a place where you can have a career and be the breadwinner for your family... Take my youngest son, for example. He started as a welding apprentice. He came here and he has been steadily getting educated, paid to go to college through our cooperative program. I mean, once he gets all the way through, he's gonna be an engineer - first one in the family to go to college (FOCUS GROUP, 06/06/2011).

Why, then, has Avondale produced good jobs? First, it should be noted that this was not always the case. Avondale was known as a racially-divided place a worker went to get hurt.

The safety record was just horrendous; people were getting killed... Before, this was just plain a bad place to work. People would ask me, 'How can you stay there?' Before the union, the reputation was that Avondale was a place you went to die (FOCUS GROUP, 06/08/2011).

Another focus group participant remembered, "Back in the 1960s, if you were black, you could work here but you wouldn't ever be anything higher than a helper. Just a helper role! I was in the military; I had faced hardships; this place was limiting me". Another worker observed, 
Before, the foreman could hold you down. They told me straight out - you will never make top money here... When I started, I was making $\$ 2.30$ an hour, and the only way you could survive was to work overtime, 45 or 50 hours a week, just to get those extra hours to make ends meet. The yard grew; the number of docks increased; but, we didn't see the benefits (FOCUS GROUP, 06/08/2011).

What changed things for Avondale workers was the union, and the union was won only through struggle. As one worker related during a focus group,

winning the union was not easy. In fact, the hardest part was getting people together, getting them to feel like they didn't have to be afraid to stand up. The company would fire people, and lots of people lost their job around the time of the organizing. It was a way of scaring people.

Another worker affirmed a similar feeling,

Lots of people were scared they'd lose their jobs. I wore my stickers, I went to the hearings, and I knew they couldn't legally fire me, and that knowledge kept me strong. Still, the company tried to divide us, bring us in one by one and offer us stuff. They made us targets, offered us better positions, like trying to make us foremen.

"It wasn't just that," observed the first worker,

I think I must have taken 15 urine tests in those days. You had to be clean; you had to be on time all the time; you had to know your job better than anyone and not make any mistakes. They were looking for an excuse to fire you if you were trying to help organize (FOCUS GROUP, 06/08/2011).

In their struggle for a union, workers learned unity and discipline,

You have to understand that during the union drive we had to be strong. This was our third try, and we had lost the first two. We lost before because the company fired us, intimidated us, told lies and tried to sweet talk us out of the union. 'What would it take', they asked me, and I told them, 'I want for my kids the same thing you give to your kids. When you can offer me that, then we can talk.' The manager just turned around and walked away (FOCUS GROUP, 06/08/2011). 
To win their struggle, workers came together with friends and neighbors outside the yard, knowing that winning better conditions in the yard would reverberate throughout the community.

\begin{abstract}
People look at me and they see a hardnosed, six foot five, 250 pounder, and they know I had my confrontations. But, as we were organizing the union, we needed help from the community. We organized marches, went to the churches, we took action with them. We sent our younger members out into the neighborhoods to talk to people, get them involved, so they would understand and stand by us. Winning the union was something we all had to do together; we knew that unionizing to make our jobs better would make our community better... The union picked up this community and carried it on its back. We held this community together, and we were known around the world. Did you know they made a documentary about us? We have a legacy. Brothers, fathers, mothers, sons and daughters - multiple generations could stay together because of this shipyard (FOCUS GROUP, 06/06/2011).
\end{abstract}

Ultimately, the union struggle was successful, and Avondale workers won their representation.

I remember the fliers we used said 'Justice at Avondale,' and that was what it was, 'Justice at Avondale'... Making this a good place to work was the struggle of the union, so all of us would be able to make it on the earnings we took home... I knew right and wrong, and the union was right for the people. We took this place from something like 14 or 15 different pay scales down to something more reasonable, where everyone could get what they deserve (FOCUS GROUP, 06/08/2011).

One worker noted that

It's important to tell the whole story here also. It's not just us, the blue-collar guys who are threatened by the shutdown; it's also the white-collar folks, the engineers. Some of those people have worked up from the blue-collar work, put their kids through school, let them move on and become engineers. They get to work over in that big building, and that is what the union is about - letting generations build from one to another

"That's right," affirmed another, 
With the apprentice program, they start to recruit people from within, move them up and eventually even into management. Imagine, from the street and all the way up to white collar. This was a real career, a route into the middle class. All of this was because of the union (FOCUS GROUP, 06/08/2011).

Success in organizing and defining the terms of their work created a special kind of pride for Avondale workers.

When I think of the work we did, I'm proud. You look at the TV, and they used to have this show Hawaii 5-0. During the music, the opening part, when they show the ships in the ocean, the big Navy destroyers, those are ours. We made those ships. That was a good feeling. I made those, and everybody was seeing them

Another worker echoed, "I was in the military for 26 years, and every so often I'd get called up from work. One of those times, I was even assigned to a ship that I had built. Imagine that, a boat I built and was then going to serve on" (FOCUS GROUP, 06/08/2011).

Still, despite pride in the products of their labors and the victories they won, the workers are realistic, even cynical, about the prospects of saving the yard. "Now, it's just like the unionization drive; they want to put us back into that scared mindset. They are watching us all the time now, just looking for ways to fire people, get rid of them to make it easier to close this place down" (FOCUS GROUP, 06/08/2011).

The workers have reason to be cynical, watching as Northrop Grumman took the shipyard over in 1999 by purchasing Litton Industries, the company that owned Ingalls Shipyard in Pascagoula, Mississippi and the Avondale facilities.

Grumman came in here with the plan of shutting this place down. They don't want two shipyards; it's just more capacity and more competition. When they took us over, they had a plan to shut one yard down in 10 years. Look at them now; that's what they did. And they started by narrowing the work. They turned down the commercial and the non-military jobs; they just wanted the Navy contracts, and ultimately they didn't even want those (FOCUS GROUP, 06/11/2011).

On one of the days of surveys at the shipyard gate, the wave of workers was followed by a few more leisurely stragglers. These were managers, not in the same rush to punch their cards as the workers, and bemused by the presence of a number of students and a professor on the doorstep of their yard. They declined the survey, citing confidentiality 
agreements with their employer, but they offered a few other comments about the prospects for the yard.

\begin{abstract}
See that gigantic crane right there and the other over there? Those cost half a million dollars each, and most of the money came from the state. After Katrina, when Pascagoula was decimated and Avondale survived, Grumman thought they could move all their new stuff to Mississippi and start fresh there with only top-of-the-line machinery. The state stopped them from moving these cranes, but they've been moving everything else (SURVEY, 11/04/2011).
\end{abstract}

In March 2011, Grumman spun off its shipyard holdings to Huntington Ingalls, saddling the newly formed company with debt in the process. The new company now controls two shipyards separated by only a few hours on the Gulf Coast, and has continued plans to consolidate activities at its Pascagoula facility while shutting Avondale, with devastating impacts on the New Orleans area and the people who live there. One observer considered a future without Avondale,

I'm 20 years old, and I wanted to make something of myself. I got my job here, and I was going to go to school, take advantage of all those programs they have to improve. I was looking forward to a life of work and getting better. Now, I don't know what I'm going to do (FOCUS GROUP, 06/08/2011).

The reason the prospects are so bleak is that outside of Avondale, there are few decent jobs on offer. People will find work, probably in the sectors that continue to grow in the region, especially leisure and hospitality, which has grown as manufacturing declines ${ }^{15}$. By definition, these sectors are lucrative in the sense that they generate growing wealth, but producing wealth is not the same as holding together communities. To bind communities, industries have to provide good jobs, for it is good jobs that produce good workers.

Jobs in leisure and hospitality tend to include seasonal and part-time work at low hourly wages. In part-time work, unionization rates are less than half the national average for full-time, year round jobs (BLS, 2011a). Also, unionization rates are even lower in the leisure and hospitality sector, with national rates of 2.7 percent (BLS, 2011b). The proud workers and hardfought, good jobs of Avondale shipyards are unlikely to be replicated in lowerpaid, part-time tourism jobs.

\footnotetext{
${ }^{15}$ Leisure and hospitality now account for 23 percent of all the jobs in New Orleans, more than twice the national average (BLS, 2011b).
} 
This poses a threat to New Orleans. Avondale produces ships, but more importantly it produces secure, capable, and public-minded members of the community. The jobs that they have struggled to create allow them to support local business, secure access to the middle class, join civic associations, organize their communities, and participate in democracy. To lose Avondale is to lose the heart and soul of an already battered community. Without its heart and soul, the community is poorer and democracy is poorer. The focus group workers put the issue pointedly, "The union picked up this community and carried it on its back... I want to know, where are our people now? Where is the support from public officials? What are you going to do about it?" directing the last question to me.

\section{Conclusion}

This project has explored the role of Avondale workers in the community. In particular, the article emphasizes the role of Avondale workers in creating the thick social bonds that hold communities together. Avondale workers earn decent incomes, patronize local businesses, join associations and support those organizations with their leadership, contributions, and civic engagement. This engagement creates the social capital that holds the community together, training people to take an interest in the public good, and driving them to seek political information. As leaders in the community, Avondale workers share that information with family, friends, and fellow workers, and build the sense that they can participate effectively in public life. They are politically engaged, vote at high rates, and participate in democratic life.

The project has also explored why Avondale shipyards produce the kinds of jobs and workers that it does. It has not always been the case that workers at Avondale could be the bedrock of their community, but that is definitely the case now. The workers themselves are clear on where their civic activism comes from - the struggle and victory of securing union representation in the workplace. That struggle was difficult, and it taught workers to intertwine their civic future with that of the community. It also secured the material benefits of income and stability that allowed workers to plan for a lifetime of increasing productivity, income, and generational advancement.

With the threat of closing on the horizon, it is clear that some basic questions about the New Orleans area have to be asked. Do we value sectors that prepare civic-minded and capable workers, embedded in social networks and empowered in their workplace to provide for themselves and their families with a path to decent livelihoods? Alternatively, will we build the city around sectors in which workers have little say, allowing growth and profit to occur without concern to the kinds of livelihoods provided? The workers put 
the question to me directly, and this paper is my first response. I record their story to make it the future, and not just history.

Aaron Schneider é Doutor em Ciência Política pela Universidade da Califórnia. Atualmente é Professor Associado de Ciência Política e Estudos sobre América Latina na Tulane University, em New Orleans.

Email: aarons@tulane.edu

\section{References}

ANES - American National Election Studies. Times Series Study. 2000. Available at: <http://www.electionstudies.org/studypages/2000prepost /2000prepost.htm>. Checked on: 30 nov. 2011.

. Times Series Study. 2004. Available at: <http://www. electionstudies.org/studypages/2004prepost/2004prepost.htm>. Checked on: 30 nov. 2011.

. Times Series Study. 2008. Available at: <http://www. electionstudies.org/studypages/2008prepost/2008prepost.htm>. Checked on: 30 nov. 2011.

. Evaluations of Government and Society. 2010-2012. Available at: <http://www.electionstudies.org/studypages/2010_2012EGSS/2010_2012EG SS.htm>. Checked on: 30 nov. 2011.

BERRY, Jeffrey M. The Rise of Citizen Groups. In: SKOCPOL, Theda and MORRIS, Fiorina (Eds.). Civic Engagement in American Democracy. Washington D.C.: Brookings Institution Press, 1999. p. 367-395.

BLS. Bureau of Labor Statistics. Union Members - 2010. Washington D.C.: Bureau of Labor Statistics, 2011 a.

. Gulf Coast Leisure and Hospitality Employment and Wages. Washington D.C.: Bureau of Labor Statistics, 2011b.

BULLOCK, Charles. Redistricting: The Most Political Activity in America. New York: Rowman \& Littlefield Publishers, 2010.

COLEMAN, James. Social Capital and the Creation of Human Capital. American Journal of Sociology, Chicago, v. 94, p. 95-121, supplement, 1988. 
DE TOCQUEVILLE, Alexis. Democracy in America. New York: Penguin Classics, 2003.

GALSTON, William. Political Knowledge, Political Engagement, and Civic Education. Annual Review of Political Science, Palo Alto, v. 4, p. 217-234, jun. 2001.

KENNY, Chris. Political Participation and Effects from the Social Environment. American Journal of Political Science, Austin, v. 36, n. 1, p. 259-267, feb. 1992.

MORRELL, Michael. Deliberation, Democratic Decision-making, and Internal Political Efficacy. Political Behavior, New York, v. 27, n. 1, p. 49-69, mar. 2005.

ORTIZ, Elaine. Who lives in New Orleans and the Metro Area Now? Brief and Data Tables. New Orleans: Greater New Orleans Community Data Center, 2011.

PUTNAM, Robert. Making Democracy Work: Traditions in Modern Italy. Princeton: Princeton University Press, 1994.

. Bowling Alone: The Collapse and Revival of American Community. New York: Simon and Schuster, 2001.

RIDLEN RAY, Marcella. Technological Change and Associational Life. In: SKOCPOL, Theda; MORRIS, Fiorina (Eds.). Civic Engagement in American Democracy. Washington D.C.: Brookings Institution Press, 1999. p. 297-329.

SCHLOZMAN, Kay; VERBA, Sidney; BRADY, Henry. Participation's not a paradox: The view from American activists. British Journal of Political Science, Cambridge, v. 25, p. 1-36, jan. 1995.

. Civic Participation and the Equality Problem. In: SKOCPOL, Theda; MORRIS, Fiorina (Eds.). Civic Engagement in American Democracy. Washington D.C.: Brookings Institution Press, 1999. p. 427-460.

SEN, Amartya. Capability and Well-Being. In: NUSSBAUM, Martha; SEN, Amartya (Eds.). The Quality of Life. New York: Oxford Clarendon Press, 1993. p. 30-53.

Human Rights and Capabilities. Journal of Human Development, Basel, v. 6, n. 2, p. 151-166, jul. 2005. 
THOMPSON, Richard. Avondale Shipyard Incentive Package will bring Quick Results. Times Picayune, 23 oct. 2011. Available at: <http://www. nola.com/business/index.ssf/2011/10/officials_confident_incentive_1.html >. Checked on: 30 nov. 2011.

TIMES PICAYUNE. 1938: Avondale Shipyard Opens on the West Bank. Times Picayune, 11 nov. 2011. Available at: <http://www.nola. com/175years/index.ssf/2011/11/1938_avondale_shipyard_opened.html>. Checked on: 30 nov. 2011.

USLANER, Eric; BROWN, Mitchell. Inequality, Trust, and Civic Engagement. American Politics Research, Champaign, v. 33, n. 6, p. 868-894, nov. 2005.

VALENTINO, Nicholas; GREGOROWICZ, Krysha; GROENENDYK, Erick. Efficacy, Emotions, and the Habit of Participation. Political Behavior, New York, v. 31, n. 3, p. 307-330, nov. 2009.

\section{Interviews, Focus Groups, and Surveys}

Interview, LWC (Louisiana Workforce Commission), 11/16/2011. Focus Group conducted, 06/06/2011, 06/08/2011, 06/11/2011.

Surveys conducted 10/12/2011; 10/17/2011; 10/19/2011; 10/28/2011; $11 / 4 / 2011$. 
A SITUAÇÃO DAS AMÉRICAS:

DEMOCRACIA, CAPITAL SOCIAL E EMPODERAMENTO

\section{Appendix}

Table 1

\begin{tabular}{l|l|l}
\hline & Avondale Pct & NES Pct \\
\hline Own home & 63.0 & $47.0^{*}$ \\
\hline Own car & 89.1 & $80.2^{+}$ \\
\hline Married & 61.8 & $50.1^{+}$ \\
\hline Involved in Union & 65.5 & $12.4^{*+}$ \\
\hline Involved in church or religious establishment & 53.6 & $15^{+++}$ \\
\hline Involved in political party & 21.4 & $71.3^{++++}$ \\
\hline Involved in neighborhood association & 19.0 & $9^{+++}$ \\
\hline Involved in sports club & 14.3 & $17^{+++}$ \\
\hline Involved in veteran's affairs group & 11.9 & $2^{+++}$ \\
\hline Involved in civil rights organizations & 9.5 & $1.8^{++++}$ \\
\hline Involved in professional association & 9.5 & \\
\hline Involved in environmental protection group & 9.5 & $2.7^{++++}$ \\
\hline Involved in arts or humanities & 8.3 & \\
\hline Involved in women's rights organization & 7.1 & $5.5^{+++}$ \\
\hline Involved in ethnic cultural organization & 6.0 & $2^{+++}$ \\
\hline Donate Money & 48.8 & $62.5^{++++}$ \\
\hline Attend Meetings & 52.4 & $20^{++++}$ \\
\hline Get others to attend meetings & 32.1 & $17.4^{+++}$ \\
\hline Distribute information & 32.1 & $17.5^{+++}$ \\
\hline Go to public events & 41.7 & $39.2^{++++}$ \\
\hline Recruit others & 28.6 & $17.4^{+++}$ \\
\hline Organize activities & 22.6 & \\
\hline Serve a leadership position & 25.0 & \\
\hline Vote in an election & 71.4 & $62^{+++}$ \\
\hline Past year, attend government meeting/other public meeting & 39.3 & $14^{+++}$ \\
\hline Past year, attend march, rally, demonstration, or protest & 20.2 & $4.1^{++++}$ \\
\hline Past year, discuss labor issues with friends/family & 71.4 & $70.1^{++}$ \\
\hline Past year, discuss politics, civil rights, women's rights & 61.9 & \\
\hline Past year, sign a petition & 48.8 & \\
\hline Past year, attend meeting to discuss labor issues & 36.9 & $8.4^{+++}$ \\
\hline Past year, attend meeting to discuss politics & 14.5 & $16^{+++}$ \\
\hline Past year, phone, email, mail elected official & 23.8 & $31.8^{++++}$ \\
\hline After Katrina, rebuild home or replace lost items & 67.5 & \\
\hline After Katrina, help a family member & 76.2 & \\
\hline After Katrina, help a friend & 70.2 & \\
\hline After Katrina, help another member of the community & 58.3 & \\
\hline After Katrina, help a coworker & 52.4 & \\
\hline & & \\
\hline trome ownsho & & \\
\hline
\end{tabular}

*Home ownership in New Orleans area (ORTIZ, 2011).

**National rate of unionization (BLS, 2011a).

${ }^{+} 2000,{ }^{++} 2004,{ }^{++} 2008,{ }^{+++} 2010$ 
A SITUAÇÃO DAS AMÉRICAS:

DEMOCRACIA, CAPITAL SOCIAL E EMPODERAMENTO

Table 2

\begin{tabular}{|c|c|c|c|}
\hline & $\begin{array}{l}\text { Strongly } \\
\text { Disagree or } \\
\text { Disagree }\end{array}$ & $\begin{array}{l}\text { Neither } \\
\text { Disagree nor } \\
\text { Agree }\end{array}$ & $\begin{array}{l}\text { Agree or Strongly } \\
\text { Agree }\end{array}$ \\
\hline Very interested in politics & 17.3 & 14.8 & 67.9 \\
\hline Politics so complicated & 47.6 & 23.8 & 28.8 \\
\hline $\begin{array}{l}\text { As well informed about } \\
\text { politics }\end{array}$ & 12.4 & 22.2 & 65.4 \\
\hline Don't have any say & 47.5 & 13.8 & 38.8 \\
\hline Pretty good understanding & 9.9 & 17.3 & 72.9 \\
\hline Public officials don't care & 25.0 & 20.0 & 55.0 \\
\hline $\begin{array}{l}\text { I'm well qualified to } \\
\text { participate }\end{array}$ & 28.8 & 25.0 & 46.3 \\
\hline $\begin{array}{l}\text { I do as good a job in public } \\
\text { office }\end{array}$ & 23.4 & 44.4 & 32.1 \\
\hline \multirow[t]{2}{*}{$\begin{array}{l}\text { Not much to affect } \\
\text { government }\end{array}$} & 46.2 & 20.5 & 33.3 \\
\hline & Not/Slightly & Moderately & Very/Extremely \\
\hline $\begin{array}{l}\text { When you think about the } \\
\text { work you have done at } \\
\text { Avondale, how proud does } \\
\text { that make you feel? }\end{array}$ & 4.8 & 13.1 & 82.2 \\
\hline $\begin{array}{l}\text { When you think about the } \\
\text { closing of the shipyard, how } \\
\text { angry does that make you } \\
\text { feel? }\end{array}$ & 18.3 & 6.1 & 75.6 \\
\hline
\end{tabular}

Table 3

\begin{tabular}{l|l|l|l}
\hline & Times & \multicolumn{2}{l}{ Worker Experience } \\
\hline Per week, groceries & 2.3 & $0-10$ years & 45 \\
\hline Per week, eat out & 2.1 & $11-20$ years & 17 \\
\hline Per week, drug store & 3.1 & $>20$ years & 21 \\
\hline Per week, talk about politics & 3.0 & Missing & 1 \\
\hline Per week, talk about closing of shipyard & 4.9 & & \\
\hline Per week, get news & 5.5 & & \\
\hline Last month, not enough sleep & 9.4 & & \\
\hline Last month, one drink & 4.7 & & \\
\hline Last month, worried, tense, anxious & 7.4 & & \\
\hline Last month, cared for friend/family member & 7.9 & & \\
\hline Per month, average church contribution & $\$ 148$ & & \\
\hline
\end{tabular}

Texto recebido em 30/01/2012. Aprovado em 27/03/2012. 